\title{
A LABORATORY CLASS FOR THE STUDY OF \\ "MIDDLETOWN" AND ITS ENVIRONMENT
}

A1 thea L. Stoecke1

Ball State University

The history most meaningful and relevant to average people is the study of the background of the problems they must face and resolve in the community where they live. Individuals learn, like and understand best what they discover through their own intiative, research, and writing. This is the philosophy behind the development of a laboratory class for the teaching of history to undergraduates at Ball State University in Muncie, Indiana.

The class was designed to use documents and manuscripts to teach the nature of history and historical research and was a complete departure from the regular lecture and textbook method. Here, students through their own research learn how the historian defines an area of research, selects sources, evaluates materials, uses secondary works and writes his or her findings. They also learn to evaluate the research and writings of other historians. Through research on such subjects as law and justice, a labor force, local government, population movements, land sales, care of the unfortunate, and rivalries of political parties and economic groups students can obtain an understanding of the development of basic American institutions.

Ball State University is particularly fortunate in having the Delaware County, Indiana, archives, a collection of thousands of documents, ledgers, and manuscripts illustrating many aspects of local history from the founding of the county in 1827 to the present. The sheer bulk of material makes it well adapted for research by undergraduates. Local and other Indiana newspapers, census records, state laws, congressional records, reminiscences of local residents, and city and county records still downtown, supplement the archives. The University continues to enlarge its research collection as materials become available from public and private sources.

In the fall of 1968 the experiment began with the first classes composed of honor students. These and subsequent students were so enthusiastic about the chance to do original research and learn what they felt was a "new kind of history" not found in ordinary classes that after two years the trial courses became a permanent part of the history department offerings, "History 220, A Laboratory Course in American History." It has no prerequisites, students are no longer screened and those of all ranges of ability enroll. Students range from freshmen to seniors, with the mafority being sophomores. The course can meet a general studies requirement in social science and a number of students with varied career goals elect it instead of a survey course in American History. History majors and minors take it in addition to their regular courses.

Classes are conducted in a laboratory format and are held in the archives room. Twenty has been set as a maximum class size for optimum guidance purposes, and because more students cannot be accommodated physica1$1 \mathrm{y}$ without interference with each other or injury to the documents. Time must be taken each year to impress upon the classes the fragility of the research material and the need for care in handling it, although most individuals are thrilled and somewhat awed in their initial contact with the manuscripts. Documents more frequently used are placed in clear acetate folders for protection. With proper surveillance undergraduates can enjoy unique research opportunities.

The core of the research collection is the Delaware County archives acquired by the University in 1966 when the county offices vacated the old courthouse and found it impossible to move all noncurrent materials. Professors, students and employees of Ball State cleared the attic and 
basement storage rooms of many years' accumulation of records. The earliest records had been moved from an older courthouse and all were in a state of dirt, disorder, and disrepair when moved by the University. Today the collection is housed in the University library. Manuscript documents have been cleaned, arranged, and filed and the ledgers placed on shelves, making use of them possible even though more professional indexing and arranging must still be done.

This collection provides an endless variety of research material in political, social, and economic history for countless students at every level of maturity. Delaware County, Indiana, is representative of the entire Middlewest, and the county seat of Muncie is famous as the Lynd's Middletown. Problems of settlers can be traced back from Delaware County to colonial America and occasionally to England. The development of local government can be seen in records from frontier days to the present.

Students have studied immigration into Delaware County by examining a number of applications for naturalization. Through inspection of justice of the peace reports of fines collected they observed the operation of laws and local government. They saw the labor system developing in the indentures of apprenticeship for bound-out children. Nineteenth century poor relief was examined through bills presented to the county by the overseers of the poor and records describing the building of the county poor farm. One entire class discovered the problems of road building and maintenance from the reports of road viewers and supervisors. The Civil War draft and soldier recruitment was revealed in hundreds of applications for the County bounty. Letters of veterans occasionally included with the applications and describing war experiences offered an opportunity for editing. ${ }^{1}$

At the first meeting of the class the student is given a manuscript which will form the basis for a short introductory paper. This is to acquaint the novice with reading handwritten, poorly spelled, and faded documents and to develop his ability to extract data from primary material and place it in a meaningful, well-organized form. Each student also receives a manila folder for research materials and a mimeographed sheet with questions to guide research. These questions suggest backgroud research, legal information, and biographical guides to help in building a setting for the document. Other questions suggest the type of data to be extracted from the manuscript. A bibliography of printed primary and secondary sources is also provided.

This first student paper is recognized as an exercise to train for other more significant projects, but even here some students are able to use initiative in selection of background and illustrative material or to get ideas for other projects. Many students are apprehensive about writing papers and insecure about the grading technique for the course. When assured that they are not competing with each other and will have a chance to rewrite papers to meet the required standard of quality they relax and are willing to learn from their mistakes.

After the first project is completed the entire class discusses the problems encountered in research and subjects available for future study. The first papers are carefully graded and suggestions made for improvement. Students are given the option of keeping the grade earned or reworking their papers for higher grades. Most do the latter, and the same option is given for later projects. Most of the papers in their earliest form show relatively adequate research but are awkwardly written and contain too much quoted riaterial. The majority of these writers find narrative history enjoyable but have difficulty in drawing conclusions and analyzing data. 
discussing and assigning possible subjects for the next project, Occasionally topics are selected which are best researched by a group. In that case the entire class can work on a general project with students seated at different tables concentrating on related aspects of the subject and exchanging information. This type of research usually culminates in a group paper summarizing research findings or an index or a map. Sometimes two or three students choose a similar topic and if possible divide the research and writing. The optimum number working on the same project is three or four students; otherwise, distribution of work, and responsibility of each individual is difficult to maintain and fair evaluation of each student impossible. The majority of students prefer to work individually and spend most of the remainder of the quarter on one major project although some have done two or three limited papers on different subjects.

Students are not confined to the classroom (archives) if their particular subject requires work in other parts of the University Library or off campus, but it is best to have even the better students report to the instructor at least once or twice a week on their progress and problems; otherwise, they get sidetracked, burled in irrelevant material, or become frustrated because of illusive data. Occasionally students come to class with preconceived ideas which do not fit into the format of the class or decide upon a topic and spend too much time searching for evidence which does not exist. Most need assistance in accepting a limited subject governed by the available evidence. Such guidance helps keep up individual enthusiasm through the sharing of new found information and aids the student in the development of his or her topic.

Published county histories give students some guidance in their research, but most of the actual records have never been studied by scholars. The most mentioned values students see in the laboratory course are the chance to do something different; to write something original; to feel that they have made some small contribution to knowledge. Student papers are kept on file in the archives for reference by those using the collection, and the knowledge that others may depend on the accuracy of his or her data provides the individual student an incentive for careful work that no mere grade ever could.

At the conclusion of each class students criticize the course in terms of method and subject explored. The value most students list first is the experience in organizing data and developing it into an essay under supervision. The greatest difficulty is to develop and express original ideas from primary material. Many indicate the transfer of the ability they have acquired from this experience to other courses has been and will be of lasting value. Students at the beginning of the course are sometimes disappointed in the limited geographic area covered by the records but, because of the varlety of topics available for investigation and their relevance to other sections of the United States, few have become disgruntled or dropped the course.

Response to the class has been good. Some elect to take it twice, as eight hours of credit are permitted. The majority who have enrolled in the laboratory class have been discontented with large lecture classes and are seeking something different. Many have also expressed disillusionment with college survey courses which repeat much that was taught in high school.

The laboratory course was developed at Ball State after the University had acquired the Delaware County Archives and housed them on campus. However, it would seem possible that with some imagination and effort a similar course could be adopted at other schools with variations for local conditions. Today, many counties, cities and towns are placing their records on microfilm to save space and are discarding the originals. Some selection might 
be made from the records to be discarded and/or the microfilm. A course could then be developed on the Ball State model. Another possibility could be the utilization of records still found in city of county buildings. In either case careful planning would be necessary and full cooperation of the local and school officials acquired before such an undertaking was begun.

This type of course was not planned to take the place of traditional subject matter courses, but to supplement them by concentration on a particular geographic area, small in size, but typical of larger areas and representative of the development of much of the United States. Through examination of the records of one locality students obtain an understanding of the growth of American institutions from the simple to-complex, and also learn the process and method of historical research and writing. This fresh approach to data reveals a new dimension to history.

\section{NOTE}

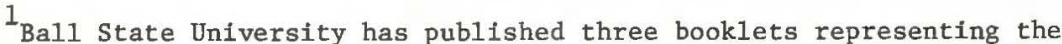
work of the laboratory class. The first, American History for Honors Freshmen, Report on an Experimental Laboratory Class at Ball State University (1969), evaluates the original classes. A second, published in 1971, shows how one class worked together on the same subject, A Study of Delaware County, Indiana, Based on Data Obtained from a Series of Maps and Reports Sent in 1845 from the District Road Supervisors to the County Auditor - The Work of Students in a Course in American History at Ball State University. The most recent booklet is made up of some papers done during the last four years and was published in 1975. It is entitled Delaware County, Indiana: The Pioneer Period 1827-1850. The first two books may be obtained without charge from Althea Stoeckel, Ball State University, Muncie, Indiana, 47306. The third can be purchased from the Ball State University Bookstore for $\$ 2.04$. 